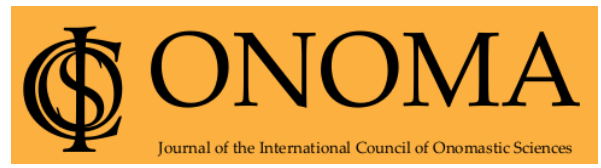

Onoma 56

Journal of the International Council of Onomastic Sciences

ISSN: 0078-463X; e-ISSN: 1783-1644

Journal homepage: https://onomajournal.org/

\title{
Parallel naming practices or names in contact? The example of Syrian first names in Sweden
}

\section{Linnea Gustafsson*}

Halmstad University, Sweden

To cite this article: Gustafsson, Linnea. 2021. Parallel naming practices or names in contact? The example of Syrian first names in Sweden. Onoma 56, 149-165. DOI: 10.34158/ONOMA.56/2021/8

To link to this article: https://doi.org/10.34158/ONOMA.56/2021/8

(C) Onoma and the author.

\section{Article history}

Received on 17 April 2021.

Final form accepted on 6 December 2021.

Published online on 13 December 2021.

\section{Parallel naming practices or names in contact? The example of Syrian first names in Sweden}

Abstract: The aim of the article is to describe the frequency and phonological aspects of Syrian first names in Sweden. The data is taken from Syrian citizens who were living in Sweden and had been in contact with the Syrian embassy in Stockholm between 2014 and 2018. In total, 1,119 first names (tokens) were studied: 328 are female names and 791 are male names. The research questions in focus are as follows:

1) What similarities and differences exist between Syrian female and male first names, regarding both frequency and phonological aspects?

2) What similarities and differences exist between the first names of Syrian and Swedish citizens in Sweden, regarding frequency and phonological aspects? 
3) What are the possibilities of native Swedish parents accepting Syrian first names for their own children?

The results show differences between female and male first names with regard to variation in first names. Further, there are similarities as well as differences between Syrian and established Swedish first names, which may lead to a lack of acceptance of using Syrian first names to name children of native Swedes. The starting point for the analysis is contact onomastics and the question of whether the Swedish naming practice is (or is not) undergoing a change due to names in contact.

Keywords: First names, Syria, Sweden, name frequencies, sounds.

\section{Pratiques d'appellation parallèles ou noms en contacts ? L'exemple des prénoms syriens en Suède}

Résumé : L'objet de l'article est de décrire la fréquence et les aspects phonologiques des prénoms syriens en Suède. Les données proviennent de citoyens syriens qui vivaient en Suède et qui avaient été en contact avec l'ambassade de Syrie à Stockholm entre 2014 et 2018. Au total, 1119 prénoms (témoignages) ont été étudiés : 328 sont des prénoms féminins et 791 sont des prénoms masculins. Les questions de la recherche sont les suivantes :

1) Quelles similitudes et différences existent entre les prénoms féminins et masculins syriens, tant en ce qui concerne les aspects de fréquence que de phonologie?

2) Quelles similitudes et différences existent entre les prénoms féminins et masculins des citoyens syriens et suédois, tant en ce qui concerne les aspects de fréquence que de phonologie?

3) Quelles sont les possibilités pour les parents suédois natifs d'accepter des prénoms syriens pour leurs propres enfants?

Les résultats montrent des différences de variation entre les prénoms féminins et masculins. En outre, il existe des similitudes ainsi que des différences entre les prénoms des Syriens et les prénoms des Suédois établis, ce qui pourrait présumer un manque d'acceptation par les Suédois natifs d'utiliser les prénoms syriens pour leurs enfants. Le point de départ de l'analyse est l'onomastique de contact et la question de savoir si la pratique suédoise d'appellation est (ou n'est pas) en cours de changement en raison des noms en contact.

Mots-clés : Prénoms, Syrie, Suède, fréquence des prénoms, sons.

\section{Parallele Namensgebungspraktiken oder Namen im Kontakt? Das Beispiel der syrischen Vornamen in Schweden}

Zusammenfassung: Ziel des Artikels ist es, die Frequenz und phonologischen Aspekte syrischer Vornamen in Schweden darzustellen. Die Daten stammen von syrischen Staatsbürgern, die in Schweden wohnhaft und mit der syrischen Botschaft in Stockholm zwischen 2014 und 2018 in Kontakt waren. Insgesamt waren 1119 Vornamen (Tokens) Gegenstand der Studie: 328 weibliche und 791 männliche Namen. Die zentralen Forschungsfragen lauten:

1) Welche Ähnlichkeiten und Unterschiede bestehen zwischen syrischen weiblichen und männlichen Vornamen hinsichtlich der Frequenz und der phonologischen Aspekte? 
2) Welche Ähnlichkeiten und Unterschiede bestehen zwischen den Vornamen der syrischen und schwedischen Staatsbürgerinnen und Staatsbürgern in Schweden hinsichtlich der Frequenz und der phonologischen Aspekte?

3) Welche Möglichkeiten bestehen für gebürtige schwedische Eltern, syrische Vornamen für ihre eigenen Kinder anzunehmen?

Die Ergebnisse zeigen Unterschiede zwischen weiblichen und männlichen Vornamen in Hinblick auf die Variation der Vornamen. Des Weiteren gibt es Ähnlichkeiten ebenso gut wie Unterschiede zwischen syrischen und gängigen schwedischen Vornamen, was zu einer mangelnden Akzeptanz bei der Verwendung syrischer Vornamen für Kinder von gebürtigen Schweden führen kann. Ausgangspunkt für die Analyse ist die Kontaktonomastik und die Frage, ob sich die schwedische Namensgebungspraxis aufgrund der Namen im Kontakt im Wandel befindet (oder nicht).

Schlüsselbegriffe: Vornamen, Syrien, Schweden, Namenfrequenzen, Laute. 


\title{
Parallel naming practices or names in contact? The example of Syrian first names in Sweden ${ }^{1}$
}

\author{
LINNEA GUSTAFSSON
}

\section{Introduction}

As a result of global migration, name contact, as well as language contact, may occur and this contact can, over time, influence the naming practices of the majority group as well as the minority one. As the choice of first names often is a question of culture (Lawson 2016), it can be a reliable indicator of the degree of integration between groups in a society. The diversity of first names that now exist among Swedish inhabitants has its origin in many different cultures; there is clearly a need to increase our knowledge and understanding of these names.

Personal names are closely related to personal identity, but they are also important to group identity. The name is obviously a concern for the bearer, but it also indirectly concerns those around the person who need to use the name. It is evident that names are part of cultural heritage and are inherently worth preserving. Therefore, it may be of interest to study the effects of when people of different cultures are in contact. For this purpose, I have chosen the naming practice of the most recent refugee group to arrive in Sweden, i.e. Syrians, to study. Culturally, linguistically, historically and so on, there are still major differences between the Syrian and the Swedish populations and, accordingly, the choice of a name can become an act of power with respect to a group's visibility. In these cases, it usually comes down to the specific type of name, i.e. affiliation with a certain language or onomasticon. Thus, the one who has power over naming practices also has power over the external presentation of the group either as a minority in its own right or just as a part of the majority group, and, therefore, names often acquire an ideological and political significance (Frändén 2014: 79).

The influx of Syrian refugees into Sweden increased heavily as a result of the civil war in Syria, reaching its height during the autumn of 2015. In 2018, about 186,000 people living in Sweden had been born in Syria (befolkningsstatistik), meaning that Syrians had become the largest immigrant group in Sweden, ahead of the Finnish group (Rogberg 2017). We do not know how long the Syrians will stay in Sweden, but earlier experiences of refugees

An abbreviated version of this article is available in Swedish (Gustafsson in press b). 
(e.g. those from Chile during the 1970s and those from Bosnia at the beginning of the 1990s) indicate that many people in this group will stay at least several decades (www.scb.se: befolkningsstatistik). Many children have been born to Syrian parents in Sweden or arrived here with their parents at an early age, which suggests that they are quite firmly rooted in Sweden.

\section{A naming practice in change and names in contact}

The point of depart of this article is that contact onomastics must, like all questions of language contact, be related to different sociocultural factors, to the language users, and to the languages in question. Given this background, name change is assumed to depend on external contacts and not on internal processes of language change (Sandnes 2016: 541). If the question is discussed in linguistic terms, names that are taken from other languages can, therefore, be described as translations and accommodations. A practical example of this has recently received attention in a study in the Norwegian context by Guro Reisæter (2012), which looks at how immigrants' first names have changed to accommodate Norwegian spelling as well as pronunciation.

The specific naming practices of a group may be explained by the strong social ties that exist between individuals who have close contact with each other (Bramwell 2016: 267; Milroy 1992: ch. 6). As the people in such a group tend to affect each other, the children are often named in similar ways (Aldrin 2011: ch. 11). For a further deployment of the names between different groups, the so-called weak ties that exist between passing acquaintances who can serve as a source of inspiration for first names that eventually can spread to other groups in society, are needed. From another perspective, the argument explains how the choice of first names can be a manifestation of culture or identity (e.g. Aldrin 2011; Gustafsson 2002), indicating the symbolic function of names.

Status, prestige, and group solidarity are important variables for all external language change, including name change. An example of the importance of status and prestige in names may be found in innovations in first names, which, at least throughout the nineteenth century, were introduced by parents in higher social groups, like the nobility and the royal family, before they continued to spread throughout the other social layers (Gustafsson 2002: ch. 8; Otterbjörk 1979b: 25-26, 33-34). One explanation for the diffusion of naming practices from the upper classes to the lower is that probably only the richest people had the possibility of being exposed to the naming practice of other countries, as only they could travel, have personal contacts abroad, and foreign relatives (Otterbjörk 1979a: 15-16). During the 19th century, there was an influx of English forenames in all sorts of social classes, that continue to increase during the 20th century. From the mid-twentieth century, it can be observed that the borrowing of first names to an increasing extent also occurs 
in the lower social groups. After World War Two, for example, the working class in Sweden was attracted by Anglo-American names, which were mainly introduced to Swedish parents by magazines and foreign films and literature (Brylla 2004: 13; Ambjörnsson 1996: 5-6; Otterbjörk 1979b: 28; Gustafsson 1994: 35-37, 2002: 114-116).

When there is a contact situation between different languages, one of the languages often has more of an effect on the other than vice versa, as is the case, for example, with the influence of Finnish on Swedish in Finland (Josephson 2004: 63). In other cases, it is possible for two languages to exist in parallel over a long period without significantly affecting each other, e.g. the effect of Finnish on Swedish in Sweden (Josephson 2004: 62). These two examples illustrate how the majority language either affects the other language or resists being affected by the minority language. Consequently, languages spoken by minority groups, which often have a lower social status than the majority group, can exist for decades without leaving any notable traces on the majority language (Josephson 2004: 62-64).

Regarding first names, it may be concluded that there are two main alternatives in situations of cultural contact. The first may be observed in the increasing number of established Swedish first names that have mostly resulted from taking new first names from other cultures and languages, where there has been some contact with other groups and nationalities in the manner mentioned above (Brylla 2004: 9-11; Gustafsson 2002: ch. 8; Otterbjörk 1979b: 24-31). The second alternative is observed in cases in which the first names are not noticeably shared between groups, e.g. the Finnish (e.g. Tuula f.) and Roma (e.g. Poncho m.) first names, which have not really been adopted by native Swedish parents, even though these names have long been used in Sweden by minority groups. Such names are not only used to identify and individualise, but also to draw attention to a certain ethnic group and to keep the group together.

To sum up, the previous research shows that there has historically been a desire to copy or adapt foreign first names in Sweden when innovative parents have found new first names in dominant and high-status cultures abroad. There seems to be a difference between this kind of foreign first name, which is quite easily accepted, and first names that have already been brought into the country by low-status groups or immigrants, which are not as easily accepted by native Swedish parents.

\section{Aim}

In this study, Syrian first names are being considered from a Swedish point of view, which means that the view of the majority is being imposed on the minority's names. In defence of this approach, it can be argued that the naming practice of minorities will often be affected by those of the majority, 
so that the names will start to be pronounced and spelt in a Swedish way (Frändén 2015: 70). It is also well known that migrants often choose to avoid letters that can be perceived as problematic to pronounce for the majority group (Frändén 2014: 81). However, as it is difficult for a speaker from the majority group to study the naming practices of the minority group (cf. Meldgaard 2006: 92), I will be very careful in my analysis and, therefore, the focus of the article is a description of the Syrian name materials and a comparison with certain aspects of established Swedish naming practices. The possible development of first names in Sweden assumes that it is reasonable to speculate on the future of first names among the Syrian minority group. There are several different possibilities regarding the future of names within the group: they may either remain within the group as a form of parallel onomasticon in Sweden, or a different onomasticon may emerge in the linguistic and cultural contact situation in which both the minority group and the majority group will affect each other in some way. The observations lead to a speculative discussion of the possibilities of how Syrian first names may be considered Swedish. ${ }^{2}$ The research questions in focus are:

1) What similarities and differences exist between Syrian female and male first names, regarding both frequency and phonological aspects?

2) What similarities and differences exist between first names of Syrian and Swedish citizens in Sweden, regarding frequency and phonological aspects?

3) What are the possibilities of native Swedish parents accepting first names that are used by Syrian citizens for their own children?

\section{Material and method}

The data used in this article is first names of Syrian citizens who were living in Sweden and had been in contact with the Syrian embassy between 2014 and 2018. These materials are not complete as regards Syrian citizens - even when it comes to Syrian citizens in Sweden - but they give an orientation to naming practices in this minority group. In total, 1,119 first names (328 female and 791 male names) were studied. The materials consist of first names that are perceived as being related to different ethnic groups in Syria (e.g. Kurds and Arabs).

Dates of birth are not reported in the data and, therefore, it is not possible to draw far-reaching conclusions that explain potential name trends or name fashions. To be able to compare Syrian names and established Swedish ones, I will use two kinds of materials. The first one is a kind of register of the first names of all Swedish citizens compiled in January 1995 and presented in a published book (Allén \& Wåhlin 1995). The other materials are from Statistics Sweden (www.scb.se) and consist of first names of persons born from 1998 on.

2 The converse - how traditional Swedish first names might be accepted in the naming practice of the Syrian group - would also be interesting, but it will be left out of this article. 


\section{Syrian and Swedish first names}

There seems to be a lack of literature and articles in English on specifically Syrian first names, although some studies on names and naming practices in the Middle East exist, e.g. in Jordan (Abd-el-Jawad 1986; Salih \& Bader 1999), Kuwait (Yassin 1978), and Israel (Rosenhouse 2002). Many of these first names have a religious origin (Islamic, Jewish or Christian). If the names are non-religious, they are, like first names from other parts of the world, often taken from a semantic field that expresses positive characteristics (Brylla 2001: 23-24; Abd-el-Jawad 1986: 83-84). Non-religious male names from the Middle East often embrace characteristics like courage, bravery, and manliness, while female names reflect traditional female virtues like beauty and decency (Meldgaard 2006: 91). Furthermore, some traditional and classical Arabic first names are taken from historical persons, e.g. Tariq (Rosenhouse 2002: 102, 110) (a general who lived during the 8th century in Damaskus).

Concerning name trends and name fashions, the picture regarding Middle Eastern first names is multifaceted. Eva Meldgaard (2006: 90) argues that name trends do not exist at all among Muslim male names in Denmark and are only slightly visible among female names. This assumption is endorsed by an Islamic saying which decrees less variation among male names: "if someone has a hundred sons, they shall all be named Mohammed" (Mitterauer 1993: 185, my trans.). However, Rosenhouse (2002: 102) noticed that certain historical Arabic first names have had a revival lately, which, contrary to Meldgaard's observation, indicates changes due to fashion among Arabic names. Closely related observations have also been made by Bader \& Salih (1997: 4), who noticed that elderly people's first names are no longer used among the youngest generation in Jordan. This indicates the presence of name trends of some kind. There may be diverse reasons for the varying results of these studies, e.g. differences in materials, methods, and contexts. The latter include ethnically differentiated naming practices, as in the Middle East naming practices may differ between groups such as Muslims, Christians, Jews, Bedouins, and Kurds who, nevertheless, live near each other (Rosenhouse 2002: 107-108).

To compare Syrian and Swedish first names, Swedish materials that have been studied earlier will be used. One of the results of this study shows that variation in Swedish first names, female as well as male, has increased from 1915 to 2016. This demonstrates that Swedish parents are currently looking for more and more unusual first names and that the choice of name, therefore, has become more diversified (Gustafsson in press a). The same tendency is also noted by Kiviniemi (2003) on Finnish data. 


\section{Results and analysis}

The transcription of the Syrian first names from the Arabic to the Latin alphabet was carried out by Ratiba Hanoush of the Institute for Languages and Folklore at Gothenburg. ${ }^{3}$ The difficulties due to the different alphabets include many variants of the spelling of the same name in the Latin alphabet (e.g. Mohammad, Mohamad, Muhammad, Muhamad, Mohammed, Mohamed, Muhammed, Muhamed) ${ }^{4}$ (cf. Rosenhouse 2002: 98). At the moment when the transcriptions were made, it is not likely that there would have been any differentiation in pronunciation between the spelling variants, but the chosen way of spelling in combination with native Swedes' difficulties with Arabic pronunciation could eventually lead to a change in the pronunciation of the names. Thus, different spelling variants can gradually become different first names. ${ }^{5}$

\subsection{First names and name frequencies}

The materials consist of religious names closely related to Islam (Meldgaard 2006: 89), e.g. Ali, Mustafa, Hassan, Hussein, Mohammad, Ahmad, Omar, Amina, and Fatima. Other religious first names have an origin in both Islam, Judaism and Christianity, e.g. Maryam (Maria), Ibrahim (Abraham), and Yousuf (Josef) (Meldgaard 2006: 90). Occidental names, or names whose pronunciation probably coincide with those of occidental names, e.g. George, Lilian, Alan, Jimi, Tony, Joy, Nansy, and Pamella, also occur. It is possible that these names are preferred by parents who have a more occidental orientation (Rosenhouse 2002: 103; Salih \& Bader 1999: 34-35, 41-42).

\subsection{Variation in first names}

The 328 female first names (tokens) subsist of 211 different name variants (lemmas), and among the 791 male names (tokens), the corresponding number is 319 (lemmas). The most common female names, Fatima and Hala, are each used by $2.1 \%$ of the women in the data, and the most common male name, Mohammad, is used by $12.4 \%$ of the men. Of the women, $10.7 \%$ have a name that is taken from one of the six most common names, and among the men, the figure is $25.0 \%$. Thus, it is noticeable that the variation among female first names is much larger than among male names, even though the female

3 This may mean that the name forms in official documents (e.g. Tax registration office) can differ from this transcription. The official name forms are those that will be used in society. The reason for not using official documents is that ethnical affiliations are not registered in official documents in Sweden.

4 In my transcriptions the name is spelled Mohammad.

5 There is already some confusion on this matter, as Gerritzen (2007: 123-124) on the one hand separates Mohamad and Mohammad in the frequency tables, but, on the other, discusses them as variants of the same first name. 
data is less extensive. Among established Swedish first names, it is not possible to observe a corresponding difference in frequencies between female and male first names.

Table 1: The most common Syrian female and male first names

\begin{tabular}{|l|c|l|c|}
\hline FEMALE NAME & NUMBER & \multicolumn{1}{|c|}{ MALE NAME } & NUMBER \\
\hline Fatima & 7 & Mohammad & 98 \\
\hline Hala & 7 & Ahmad & 37 \\
\hline Amal & 6 & Ibrahim/Ibraheem & 18 \\
\hline D(o)uaa & 5 & Has $($ s)an & 16 \\
\hline Rasha & 5 & Mahmoud & 15 \\
\hline Mariam/Maryam & 5 & Fadi & 14 \\
\hline Hiba & 4 & Omar & 14 \\
\hline Huda & 4 & Yousef/Josef & 14 \\
\hline Maha & 4 & Georg(e) & 13 \\
\hline Mari(e) & 4 & Ali & 11 \\
\hline Mirna & 4 & Hus(s)e(i)n & 10 \\
\hline Mo(u)na & 4 & Samer & \\
\hline Rania & 4 & \multicolumn{2}{|l}{}
\end{tabular}

A comparison of this table (Table 1) and a frequency table of the twenty most common Muslim first names in Denmark 2005, indicates similarities as well as differences (Meldgaard 2006: 89). The most common male name in my table, as well as in the Danish, is Mohammad, which was also the most common name among boys of Moroccan origin in the Netherlands in 1999 (Gerritzen 2007: 123). Mohammad and Ahmed, the second most common male names in my table, are the two most common Arabic male names in the world (Rosenhouse 2002: 106). Among the twelve male names in my list, three-Fadi, George, and Samer - do not exist in Meldgaard's Danish table.

One of the most common female names in my materials, Fatima, is the name of the youngest daughter of the prophet Muhammad and is thus a religious Muslim first name, along with the male name Mohammad. If the similarities between my frequency table and the Danish list are rather noticeable regarding the male names, those similarities are much less pronounced among the female names. Of the thirteen most common names, the differences between the lists are numerous, and in my table, there are eight female names, D(o)uaa, Hala, Hiba, Maha, Mari(e), Mirna, Rania and Rasha, that are not present in the Danish table (Meldgaard 2006: 89). The differences in frequencies may be explained in the following ways: 1) the studied data is small and, therefore, randomised differences may have a disproportionately large impact; 2) the data in this study includes names from different ethnic groups in Syria, while the Danish study asserts that their data includes only Muslim first names, or 3) there is a fashion influence in naming practices, causing fluctuations in popularity to occur. 


\subsection{Phonetic structure of the first names}

Concerning the structure of first names, there are both similarities and differences between Syrian and established Swedish first names. In the following analysis, I will first present Swedish speakers' difficulties in pronouncing Syrian names, and then I will concentrate on the initial, medial, and final distribution of phonemes and combinations of sounds.

Some of the phonemes in Syrian first names are either unknown or hard to pronounce for native Swedes, and sometimes these sounds do not correspond to an exact letter in the Swedish alphabet. One of these is the final $-a$-sound with a sharp ending (/a:/ followed by a glottal stop) that is usually written by a double -aa, i.e. D(o)uaa. The sound exists in female as well as in male names, but in the studied material it is more often used in female names. Altogether, the sound exists in $1.9 \%$ of the Syrian names in my data, and in $0,007 \%$ of the established Swedish first names (Statistics Sweden). Another sound that neither exists in established Swedish naming practice, nor in Swedish in general, is the initial uvular fricative $/ \chi /$ which often is spelt $G h$ in the materials. In this case, the pronunciation becomes insecure and, therefore, those sounds can be perceived as very Arabic. ${ }^{6}$ The initial distribution of the sound $/ \chi /$ exists in female as well as in male names, e.g. Ghalia (k), Ghonwa (k), Ghaith (m), Ghaleb (m), Ghassan (m), Ghazi (m).

Another sound that is different from Swedish sounds is the semivowel /w/, which exists both initially and medially in Syrian first names. The sound exists in both female and male names, e.g. Intwanet $(\mathrm{k}), \operatorname{Rawad}(\mathrm{k}), \operatorname{Wafaa}(\mathrm{k})$, Warda (k), Jawad (m), Radwan (m), Tawfik (m), Waleed (m), and Wasim (m). As the letters $\mathrm{w}$ and $\mathrm{v}$ are normally pronounced in the same way in Swedish, it is difficult to draw any conclusions regarding the frequency of the sound in established Swedish first names based on the spelling. In the medial position in Syrian first names, there are combinations of sounds that either hardly exist in established Swedish first names or do not exist at all in medial position, e.g. $\mathrm{kr}^{-}{ }^{7}, \operatorname{Akram}(\mathrm{m})$ and $-\mathrm{sr}_{-}{ }^{8}$, Nisren (k). However, another phoneme, $/ \mathrm{J} /$ (often spelt -sh-), only exists to a limited extent in established Swedish names, and, in those cases, it is found in an initial position. In Syrian first names, this phoneme exists in medial or final position (to the extent of $1.6 \%$ ), e.g. Bushra (k), Rasha (k),Ahmad (m), Audisho (m),Bashar (m),Bashir (m), Hashem (m), Rashed $(\mathrm{m})$. In established Swedish names, this phoneme in the same positions is not frequent $(0.04 \%)$, except in the three names, Joshua, Natasha, and

6 It would be very interesting to analyse and discuss the difficulties from the Syrians' perspective when their first names are adapted to Swedish phonology and pronunciation.

7 The existence of $-k r$ - in medial position is $0.5 \%$ in the Syrian material and $1 \%$ in the Swedish.

8 The existence of $-s r$ - in medial position is $0.9 \%$ among the Syrian female names and among the Swedish $0.02 \%$. 
Sasha, which are used but are not yet perceived as traditional Swedish names. The fact that these three names are used might be that this sound is slowly being accepted in Swedish naming practices.

Regarding other final phonemes, there are some major similarities between Syrian and established Swedish female and male first names: vowels are more common in final position in female names and consonants are more common in final position in male names. Thus, it is slightly more common for there to be an $-a$ in final position (6.9\%) in Syrian male names than in Swedish $(1.0 \%)$ (Gustafsson in press a). Another phoneme that is more common in Syrian first names is a final $-b$, which, in Swedish names, is almost only to be found in Jakob. In the Syrian materials this is found in several male names, e.g. Agob (m), Ghaleb (m), Habib (m), Hasib (m), Ihab (m), Shihab (m), Yakoub (m), and in the female names Ghuroub (f) and Zeneb (f).

Concerning phoneme combinations in the final position, $-a d$ and -ed barely exist at all in Swedish female names $(0.01 \%$ and $0.03 \%$, respectively) and only occasionally in male names $(0.16 \%$ and $0.5 \%$, respectively). In the Syrian materials, - $a d$ is used more often in female names (2.7\%) and both -ad $(20.6 \%)$ and $-e d(1.5 \%)$ are found in male names, e.g. Raghad (f), Rawad (f), Zinad (f), Abed (m), Ahmad (m), Fahed (m), Fouad (m), Imad (m), Iyad (m), Jawad (m), Jihad (m), Joneed (m), Khaled (m), Majed (m), Mohamad (m), Morad (m), Mouhanad (m), and Rashed (m). Furthermore, -lal is rarely found among Swedish citizens $(0.01 \%)$ but is used slightly more often in the names of people of Syrian origin $(0.7 \%)$, e.g. Bilal $(\mathrm{m})$ and Dalal $(\mathrm{f} / \mathrm{m})$. Two other final combinations, -ek and $-f i k$, are also unusual in established Swedish naming practice $(0.01 \%$ and $3 \%$, respectively) but appear more often in Syrian names (0.6\% and $0.2 \%$, respectively), e.g. Tarek (m) and Tawfik (m). These combinations do not exist among Syrian female names.

In contrast, some other final phoneme combinations are equally well known in Syrian and Swedish first names, e.g. ar and -er, found in the Syrian male names Ammar and Fakher, and in the Swedish first names Einar and Alexander. Another combination that is common to the two naming practices is -in, which is used in female as well as in male names, e.g. in the Syrian $\operatorname{Amilin}(\mathrm{k})$, Alin (k), Avin (k), Nevin (k), Yasmin (k), Warshin (m), and Yasin (m), and in the Swedish Carolin, Celin, Elin, Martin, Melvin, and Robin. Another combination, -ia, exists in both Syrian and Swedish female names, e.g. in the Syrian Alia, Lia, Nazlia, Ramia, Rania, and Sinitia and in the Swedish Alicia and Olivia. Among Syrian first names, -ia also appears among male names, e.g. Trizia and Yehia. The use of -ia in male names is quite unusual in Sweden, even though Zakaria and Elia exist (cf. Nübling in press). Finally, the combination -ina is well known in Syrian female names, e.g. Adina, Amina, Hasina, and Youstina, as well as in Swedish female names. 


\section{Discussion}

The description of the naming practices of the Syrian minority group in Sweden reveals that the choice of name is far more varied among Syrian female names than among male names; however, the less extensive Syrian data must be taken in consideration. A corresponding difference does not exist among established Swedish names. Both Swedish female and male names have approx. the same degree of variation among the most common names as Syrian female names (Gustafsson in press a). One explanation of this may be that name fashions have a smaller impact on Syrian first names then on Swedish first names (Meldgaard 2006: 90). Another explanation may be that men, to a greater extent than women, are regarded as bearers of culture and tradition. As naming practices symbolise traditions, this is reflected in the choice of first names.

Further results show that, in general, Syrian as well as Swedish first female and male names follow a structure of preferred final phonemes that is found in many cultures and languages. The possibility of Syrian first names being accepted by native Swedes is probably better if there are similarities based on structures that already are known to Swedish parents. First names consisting of a structure that is used in Syrian as well as in Swedish first names in combination with a request by Swedish parents for unusual, creative, new, and innovative first names (Kiviniemi 2003; Gustafsson in press a) would probably have the capacity to be accepted. Even some male names, e.g. Amir, may have the possibility of spreading into Swedish naming practices, but changes in naming practices are often observed first among female names before they spread to male names (i.e. Abd-el-Jawad 1986: 90; Gustafsson 2002: ch. 7). It is thus doubtful whether this desire for innovative and unusual first names would extend to totally unfamiliar structure.

Concerning the integration of Syrian first names in the Swedish majority group, time is an important factor. As a result of the fact that children from different ethnic groups might grow up together in Sweden, many Syrian first names could later be accepted by the younger generation of the majority group. In addition, young persons with foreign roots and hence foreign first names are taking a more and more active part in the media landscape, something that can lead to the spread of famous peoples' first names in society (Gustafsson 1994: 31-35; Meldgaard 1997: 103). Famous people from other ethnic groups in Sweden include, for example, the entertainer Samir and the singer Laleh. Laleh has already been used by native Swedish parents as the athletic couple Carolina and Patrik Klüft has chosen it as the name of one of their daughters (Käck 2019).

There are also other external factors that may affect the integration of first names, such as the social status of a name bearer. Over time there seems to have been a shift in the status of first names from other cultures. Earlier, foreign first names were a matter for higher social groups, but increasingly 
after the Second World War the status of foreign first names appear to have declined, even though the new names still came from the dominant cultures (cf. Ambjörnsson 1996: 5-7). One group with notably low status is refugees, who can easily be subordinated in a new country.

A naming practice that differs greatly between ethnic groups may be perceived as an ethnic marker (cf. Frändén 2017: 120-124). If there is also a difference in social status between the groups, the first names may be perceived as being ethnically as well as socially distinctive. In those cases, the names usually do not spread between groups, especially not from the dominated group to the dominant one (cf. the example of Oscar's introduction in Sweden and Denmark in Kisbye 1983: 84-90). On the other hand, the choice of a first name originating in the dominated culture may be perceived as an act of solidarity regarding the subordinated group. Therefore, a first name in the dominated group can be either a stigmatising marker or an act of solidarity. This could be the case with several of the most common Syrian male names in the materials, e.g. Mohammad, Ahmad, Omar, Ibrahim, Mahmoud, and Hassan, which are strongly associated with Muslim and Arabic culture. The culture and, consequently, the stigmatisation are probably not as strong among Syrian female names, as the variation is greater. Accordingly, this could lead to a different establishment in Swedish naming practices for female and male first names. Syrian female names seem, to a greater extent than male names, to have the potential to be accepted by native Swedish parents.

\section{References}

Abd-el-Jawad, Hassan. 1986. A linguistic and sociocultural study of personal names in Jordan. Anthropological Linguistics 28(1), 80-94.

Aldrin, Emilia. 2011. Namnval som social handling. Val av förnamn och samtal om förnamn bland föräldrar i Göteborg 2007-2009 [Naming as a social act. Parents' choices of first names and discussions of first names in Göteborg 2007-2009]. Uppsala: Uppsala Universitet. (Namn och samhälle 24.)

Allén, Sture \& Wåhlin, Stig. 1995. Förnamnsboken [The book of first names]. Stockholm: Norstedts.

Ambjörnsson, Ronny. 1996. Mitt förnamn är Ronny [My first name is Ronny]. Stockholm: Bonnier Alba.

Bader, Yousef \& Salih, Mahmud H. 1997. A diachronic analysis of personal names in Jordan. Journal of Applied Linguistics 12(1), 3-13.

Befolkningsstatistik [Statistics over the population]. www.scb.se [Statistics Sweden]. (https://www.scb.se/hitta-statistik/sok/Index?Date=Anytime\& Sort $=$ relevance $\&$ Query $=$ be $0101 \&$ Page $=2 \& \mathrm{Tab}=$ scb\&Exact $=$ False $)$ (Accessed 2020-02-06.) 
Bramwell, Ellen S. 2016: Personal names and anthropology. In Hough, Carol, (ed.), The Oxford handbook of names and naming, 263-278. Oxford: Oxford University Press.

Brylla, Eva. 2001. Personnamn och genus [First names and gender]. Studia Anthroponymica Scandinavica 19, 11-29.

Brylla, Eva. 2004. Förnamn i Sverige. Kortfattat namnlexikon [First names in Sweden. A short name dictionary]. Stockholm: Liber.

Frändén, Märit. 2014. "Vi bestämde oss för att skriva namnet på ett svenskt sätt." Förnamnsval i sverigefinska familjer ["We decided to write the name in a Swedish way". Choice of first names in Swedish-Finnish families]. Studia Anthroponymica Scandinavica 32, 75-138.

Frändén, Märit. 2015. Gamla i välden men nya i Sverige. En projektbeskrivning av forskning om invandrade efternamn [Old in the world but new in Sweden. A description of a research project about immigrant surnames]. In Aldrin, Emilia \& Gustafsson, Linnea \& Löfdahl, Maria \& Wenner, Lena (eds.), Innovationer $i$ namn och namnmönster. Handlingar från NORNA:s symposium i Halmstad den 68 november 2013 [Innovations in names and name patterns. Proceedings from NORNA's 43rd symposium in Halmstad, 6-8 November 2013], 67-72. Uppsala: NORNA-förlaget. (NORNA-rapporter.)

Frändén, Märit. 2017. "En liten identitetsgrej" eller "bara en kod"? Tankar om efternamn och identitet bland svenskar med finskspråkiga efternamn [“A small thing of identity" or "just a code"? Thoughts of surnames and identity among Swedes with Finnish surnames]. In Leino, Unni-Päivä \& Forsskåhl, Mona \& Harling-Kranck, Gunilla \& Jordan, Sabina \& Nakari, Minna \& Pitkänen, Ritva Liisa (eds.), Namn och identitet. Handlingar från NORNAs 46: e symposium i Tammerfors den 21-23 oktober 2015 [Names and identity. Proceedings from NORNA's 46th symposium in Tampere, October 21-23, 2015], 115-132. Uppsala \& Tammerfors: NORNA-förlaget. (NORNA-rapporter 94.)

Gerritzen, Doreen. 2007. First names of Moroccan and Turkish immigrants in the Netherlands. In Brylla, Eva \& Wahlberg, Mats, in collaboration with Rentenaar, Rob (eds.), Proceedings of the 21st International Congress of Onomastic Sciences. Uppsala 19-24 August 2002, vol. 3, 120-130. Uppsala: Institutet för språk och folkminnen.

Gustafsson, Linnea. 1994. I förnamnens värld. Dopnamn i tre församlingar under 1900-talet [In the world of first names. Christian names in three congregations during the 20th century]. Nordiska språk, Umeå universitet. (Unpublished candidate thesis.)

Gustafsson, Linnea. 2002. Novation $i$ norr. Nya dopnamn och namngivningsmönster $i$ Skelleftebygden 1791-1890 [Innovation in the North. New Christian names and patterns of name giving in Skellefteå 
and its surroundings 1791-1890]. Umeå: Institutionen för litteraturvetenskap och nordiska språk. (Anthroponymica Suecana 12.)

Gustafsson, Linnea. In press a. Strukturella skillnader mellan svenska kvinnooch mansnamn 1915-2016 [Structural differences between Swedish female and male names 1915-2016]. Studia Anthroponymica Scandinavica 37.

Gustafsson, Linnea. In press b. Syriska förnamn i Sverige [Syrian first names in Sweden]. NORNA-rapporter.

Josephson, Olle. 2004. “Ju” ifrågasatta självklarheter om svenskan, engelskan och andra språk $i$ Sverige ["Ju" - questioning the self-evident in Swedish, English and other languages in Sweden]. Stockholm: Norstedts akademiska förlag.

Käck, Andreas. 2019. Babylyckan: "Nu har vi en hel trio" [The baby happiness: "Now we are a whole trio"]. Aftonbladet. (https://www.aftonbladet.se/ sportbladet/a/Op1Eab/babylyckan-nu-har-vi-en-hel-trio) (Accessed 202001-20.)

Kisbye, Torben. 1983. Oscar, Orla, Ossian, Selma, Malvina, Minona. Studia anthroponymica Scandinavica 1, 81-103.

Kiviniemi, Eero. 2003. Mode och smak vid val av namn [Fashion and taste at the choice of names]. In Saari, Mirja (red.), Namn och språk $i$ när och fjärran [Names and language near and far], 35-46. Helsinki: Helsingfors universitet.

Lawson, Edwin D. 2016. Personal naming systems. In Hough, Carole (ed.), The Oxford handbook of names and naming, 169-198. Oxford: Oxford University Press.

Meldgaard, Eva Villarsen. 1997. Fornavnemoder i Danmark 1820-2020 [Fashion of first names in Denmark 1820-2020]. Studia Anthroponymica Scandianvia 15, 101-112.

Meldgaard, Eva Villarsen. 2006. Muslimske fornavne i Danmark [Muslim first names in Denmark]. Studia Anthroponymcia Scandinavia 24, 87-94.

Milroy, James. 1992. Linguistic variation and change. Oxford: Blackwell.

Mitterauer, Michael. 1993. Ahnen und Heilige. Namengebung in der europäischen Geschichte. München: Verlag C.H. Beck.

Nübling, Damaris. In press. The Spelling of personal names in German and its relation to history, geography, and gender. NORNA-rapporter.

Otterbjörk, Roland. 1979a. Hur var namnet? Ett kompendium om namn - mest personnamn [What is your name? A compendium about names - mostly personal names]. Läromedel från Institutionen för nordiska språk vid Umeå universitet 6 [Study material from The Department of Scandinavian Languages at Umeå University].

Otterbjörk, Roland. 1979b. Svenska förnamn [Swedish first names]. Stockholm: Almqvist \& Wiksell. (Skrifter utgivna av Svenska språknämnden 29.) 
Reisæter, Guro. 2012. Immigrants in Norway and their choice of names: continuation or adaption? Names and identities. Oslo Studies in Language 4(2), 223-234.

Rogberg, Salomon. 2017. Historiskt skifte: fler syrier än finländare [A historical change: more Syrians than Finns]. Sveriges Dagblad (SvD). (https://www.svd.se/historiskt-skifte--nu-finns-fler-syrier-an-finlandare-isverige) (Accessed 2020-02-06.)

Rosenhouse, Judith. 2002. Personal names in Hebrew and Arabic: Modern trends compared to the past. Journal of Semitic Studies XLVII/1, 97-114.

Salih, Mahmud Husein \& Bader, Yousef T. 1999. Personal names of Jordanian Arab Christians: A sociocultural study. International Journal of the Sociology of Language 140, 29-43.

Sandnes, Berit. 2016. Names and language contact. In Hough, Carole (ed.), The Oxford handbook of names and naming, 540-553. Oxford: Oxford University Press.

Statistiska centralbyrån [Statistics Sweden]. (www.scb.se) (Accessed 202002-06.)

Yassin, Mahmoud Aziz F. 1978. Personal names of address in Kuwaiti Arabic. Anthropological Linguistics 20(2), 53-63. 